\title{
Bank-specific Factors Affecting Non-performing Loans in Developing Countries: Case Study of Indonesia ${ }^{1}$
}

\author{
Rathria Arrina Rachman ${ }^{2}$, Yohanes Berenika Kadarusman ${ }^{3}$, Kevin Anggriono ${ }^{4}$, Robertus Setiadi ${ }^{5}$
}

Received: April 26, 2018. Revised: April 30, 2018. Accepted: May 5, 2018.

\begin{abstract}
In recent decades, financial crises in various countries have often been preceded by the rise in non-performing loans (NPLs) in the banks' asset portfolios. The increase in NPLs is proven to have adverse impact on the banking sector so that understanding the determinant of NPLs is immensely crucial to ensure the efficiency and soundness of the overall economy. This study aims to shed light on bank-specific factors that affect loan default problems in developing countries whose banking sectors play a major role in the overall economy. This study analyzes panel data sets of 36 commercial banks listed in the Indonesian Stock Exchange during the period 2008-2015. Applying fixedeffects panel regression model reveals that Indonesian banks' profitability and credit growth negatively influence the number of NPLs. Moreover, banks with higher profitability are proven to have lower NPLs because they can afford adequate credit management practices. Likewise, banks with higher credit growth evidently have lower NPLs in the sense that they demonstrate more specialized lending activity and thus have better credit management systems. These findings imply that, in order to lower loan defaults that can deteriorate banks' asset quality, banks should maintain their level of profitability and increase, rather than decrease, their credit supply to debtors.
\end{abstract}

Keywords: Non-Performing Loan, Bank-Specific, Loan Default, Developing Country, Fixed-Effects, Indonesia.

JEL Classification Code: G21, C23, O10.

\section{Introduction}

In the last two decades, a remarkable series of financial crises have occurred in several countries. The recent Global Financial Crisis in 2007-2008 that was caused by credit crunch of the U.S. sub-prime mortgages resulted in an economic crash and instability in the global markets. Previously, financial crises hit fast-growing countries in East Asia in 1997, leading to a significant outflow of foreign investment funds from these economies (Deesomsak,

1 Thanks to all people who have supported this research, especially to the Research Office of Universitas Prasetiya Mulya.

2 First Author and Corresponding Author, Universitas Prasetiya Mulya, Indonesia [Postal Address: Jalan R.A Kartini (T.B.

Simatupang), Cilandak Barat, Jakarta 12430, Indonesia]

E-mail: rathria.arrina@gmail.com

3 Universitas Prasetiya Mulya, Jakarta, Indonesia.

E-mail: yohanes.kadarusman@pmbs.ac.id

4 Universitas Prasetiya Mulya, Jakarta, Indonesia.

E-mail: kevinanggriono@hotmail.com

5 Universitas Prasetiya Mulya, Jakarta, Indonesia.

E-mail: setiadi.robertus@gmail.com
Paudyal, \& Pescetto, 2004; Machrouch, Soedarmono, \& Tarazi, 2011). Financial crises are frequently marked by a hike in non-performing loans (henceforth NPLs) in banks' loan portfolios. Following the Global Financial Crises, NPLs have been under the surveillance of the government and bank management, since they are considered to be associated with bank failures and crisis (Ghosh, 2015). This phenomenon is exacerbated in countries that heavily rely on banks as financial intermediaries that allocate funds throughout the economy (bank-based economies), such as Indonesia.

In countries with bank-based economic systems, banks play a major role in the sustainability of the financial system and become the main resort for funding, as these countries' capital markets are still emerging (Moradi, Mirzaeenejad, \& Geraeenejad, 2016). Regardless of its prominence in the financial system and economy, the banking sector in Indonesia demonstrates an exceptional attractiveness compared to its neighboring countries due to its high credit growth and profitability. Figure 1 displays the status of credit growth, net interest margin (NIM), and non-performing loans (NPL) of ASEAN-5 countries in 2016. The credit growth of Indonesian commercial banks was 7.9 per cent in 2016 . 
Among the other ASEAN (Association of South East Asian Nations)-5, this rate is lower than that of the Philippines (16.1 per cent) but higher than Thailand (5.3 per cent), Malaysia (3.1 per cent), and Singapore (2.9 per cent). Interestingly, Indonesian banks' net interest margin (NIM) that reflects profitability is the second highest in the region. The average NIM of Indonesian banks is 5.4 per cent - well above the average of Philippines ( 3.4 per cent), Thailand (2.6 per cent), Malaysia (2.4 per cent), and Singapore (1.7 per cent). Within Indonesian commercial banking, the interest income accounts for 72.4 per cent of total operating income which is mostly generated from credit (Bank Indonesia, 2016). High credit growth in addition to a high interest margin has caused the Indonesian banking sector to become more attractive than that of other ASEAN countries. Unfortunately, these advantages are hindered by the riskiness of these banks, which is reflected in the high NPLs. Compared to other ASEAN-5 countries, banks in Indonesia have NPL ratio of 2.9 per cent, which is a bit lower than Thailand ( 3 per cent) but far higher than Malaysia (1.6 per cent), Singapore (1.2 per cent), and the Philippines (1.9 per cent).

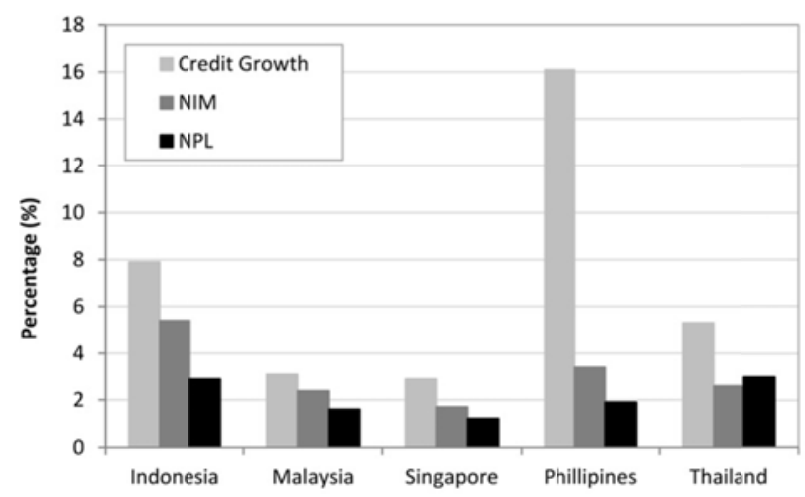

Source: OJK(2017).

Figure 1. Credit Growth, Net Interest Margin (NIM), and Nonperforming Loans (NPL) of ASEAN-5 countries in 2016

During the period of 2008-2013, the average bank NPL ratio in Indonesia decreased from 3.2 per cent to 1.69 per cent of gross loans. Nevertheless, since 2014, the NPL ratio has increased, reaching 2.9 per cent in 2016. Although the average bank NPL ratio of 2.9 per cent is still lower than the prudential guideline of the Indonesian Financial Service Authority (the OJK) of 5 per cent, the OJK report shows that 22 of the 115 commercial banks in Indonesia actually have an NPL ratio above 5 per cent (OJK, 2017). Accordingly, although the Indonesian banking sector is considerably promising, it is also risky.

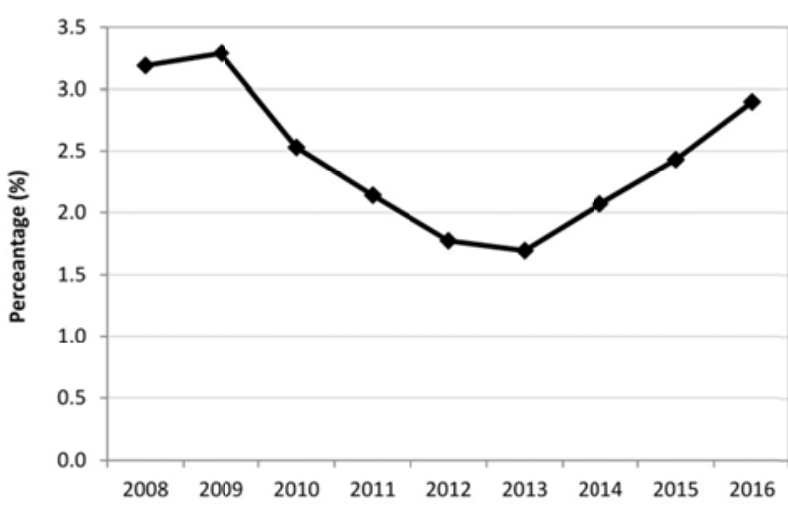

Source: OJK(2017).

Figure 2. Ratio of Non-performing Loans to Gross Loans (NPL Ratio) in Indonesia over the period of 2008-2016

The increase in NPLs that deteriorate banks' asset quality is believed to have an adverse impact on the health and efficiency of the banking sector (Zhu, Wang, \& Wu, 2014). In addition, previous research indicates that loan defaults have harmful consequences on the overall economy (for example, Barseghyan, 2010; Zeng, 2012). Considering this substantial influence, it is important for banking supervisory authorities to understand the determinants affecting loan defaults in banks' portfolio, especially in developing countries that still heavily rely on the banking sector. Empirically, loan defaults can be attributed to banks' specific aspects and macroeconomic factors (Beaton, Myrvoda, \& Thompson, 2016; Dimistrios, Helen, \& Mike, 2016; Ekanayake \& Azeez, 2015; Vatansever \& Hepsen, 2013). However, by controlling for bank-specific factors, policy makers can comprehend micro-prudential contexts and identify the impact of the NPL ratio on the lending behavior of commercial banks.

Many researchers have examined the effects of macroeconomic and bank-specific factors on loan performance of banks in Indonesia (Alexandri \& Santoso, 2015; Diyanti \& Widyarti, 2012; Poetry \& Sanrego, 2011). Therefore, studies that focus only on bank-level data in scrutinizing bank loan performance in Indonesia are noticeably limited. This study aims to comprehend bankspecific determinants affecting non-performing loans (NPLs) in the Indonesian commercial banking sector. More specifically, this study seeks to address (1) what bankspecific factors significantly affect the NPL ratio, (2) the relationships of the determinant-factors with NPL ratio, and (3) the quantitative measure of that effect. The paper is organized as follows: Section II reviews the related literature and the overview of the recent development of the Indonesian banking sector. Section III explains the methodology, Section IV explores the empirical results on 
the determinant-factors affecting the NPL, focusing on bankspecific aspects and also discusses how data and information are gathered and analyzed. The last section concludes and suggests policy implications for the Indonesian commercial banking industry.

\section{Literature Review}

\subsection{Literature on Non-performing Loan Determinants}

Non-performing Loans (NPL) can be attributed to bankspecific and macroeconomic factors (Beaton et al., 2016; Dimistrios et al., 2016; Ekanayake \& Azeez, 2015; Vatansever \& Hepsen, 2013). Among the macroeconomic factors, business cycle, inflation rate, interest rate, and exchange rates are common determinants of NPLs in banks portfolios (for instance, Beck, Jakubik, \& Piloiu, 2015; Klein, 2013; Love \& Ariss, 2013; Skarica, 2013). Meanwhile, the financial aspects of internal banks including credit growth, capitalization, loan loss provision, portfolio composition, profitability, net interest margin, efficiency, and size are common determinants of NPLs (for instance, Ghosh, 2015; Klein, 2013; Love \& Ariss, 2013).

More specifically, analyzing the effects of macroeconomic variables on loan performance in the Indonesian banking sector has also been undertaken by many researchers (for example, Alexandri \& Santoso, 2015; Diyanti \& Widyarti, 2012; Poetry \& Sanrego, 2011). Moreover, Diyanti and Widyarti (2012) find that external and internal factors such as bank size, Capital Adequacy Ratio (CAR), Gross Domestic Product (GDP), and inflation are attributed to loan defaults of commercial banks in Indonesia. However, research that focuses only on analyzing internal commercial bank-specific factors to non-performing loans in Indonesian banks is currently considered very limited.

This study focuses on identifying the bank-specific factors that significantly affect the NPL ratio in the Indonesian commercial banking sector. Recognizing very different characteristics of commercial banks in Indonesia (e.g., asset size, ownership structure, main business, core-capital grouping); it is then valuable for policy makers to understand the determinant of the NPL ratio within the individual banklevel data for the micro-prudential context. Moreover, discovering bank-specific factors is important for policy makers to comprehend the effect of NPL on the lending behavior of individual banks.

Scholars have identified bank-specific factors significantly affecting the NPL ratio, including credit growth, profitability, operating efficiency, capitalization, and income diversification. The relationships between the bank-specific determinant factors are ambiguous, and some scholars find positive while others suggest negative relations. Keeton (1999) argues that credit growth positively affects the NPL ratio, because when banks raise their credit supply, they might lower their loan interest rates and credit checks to attract debtors. Similarly, Ahmad and Bashir (2013) find a positive relationship between credit growth and NPLs. Furthermore, they suggest a procyclical credit policy hypothesis, stating that the growth of bank credit supply follows a business cycle; it goes up when the economy is booming because banks loosen their credit requirements, and vice versa. On the contrary, Boudriga et al. (2010) find that an increase in credit supply lowers loan defaults, implying an inverse relationship between credit growth and NPL. They argue that banks supplying more credit are most likely to have good credit risk scoring and management.

Empirical evidence regarding the impact of banks' profitability on NPLs also shows ambiguous relationships. Berger and DeYoung (1997) argue that highly profitable banks are less likely to become involved in risky activities that can lead to loan defaults in the future. This suggests a negative relationship between bank profitability and NPL ratio. On the other hand, Rajan (1994) suggests that a credit policy is dependent not only on the objective of maximizing profits but also on the management reputation. Therefore, bank management tends to manufacture current earnings to create a "liberal credit policy" resorting to loan defaults in the following periods. This implies a positive impact of profitability on the NPLs.

Efficiency indicates that banks run their business activities with relatively low costs. Berger and DeYoung (1997) find that reduction in cost efficiency of the US commercial banks precedes an increase in the future loan defaults. This is caused by managers who are unable to control their operating expenses as well as to practice appropriate daily operations and loan portfolio management. Nonetheless, when a subset of relatively efficient banks is scrutinized, an increase in cost efficiency is followed by a hike in loan defaults, proving the skimping hypothesis. Under this hypothesis, an increase in loan defaults occurs because the banks choose to spend a low price on underwriting and monitoring loans in the short run and bear the risk of having loan performance problems in the future.

Bank capital also empirically affects the NPL ratio in the opposite direction. On one hand, due to the moral hazard incentive, managers of low-capitalized banks tend to get involved in high-risk loans which area issued through inadequate credit scoring and monitoring (Keeton \& Morris, 1995). These risky credit activities induce a rise in loan defaults, implying a negative relationship between capital and NPL ratio. On the other hand, managers in high capital bases apply liberal policy when granting credits because 
they are assured that the banks are less likely to go bankrupt and are "too big to fail" (Rajan, 1994). Therefore, these banks are engaged in high-risk credit activities, suggesting a positive relationship between bank capital and NPL ratio.

Earnings received by banks can be distinguished as interest income coming primarily from lending activities and non-interest income coming from trading and derivative transactions. Banks with more diversified income (other than interest income) tend to be more prudent and lower their risks by having less involvement in high-risk credit activities. Hence, these banks have better loan performance, suggesting an inverse relationship between income diversification and NPL ratio (Ghosh, 2015). Another work of research by $\mathrm{Hu}, \mathrm{Li}$, and Chiu (2004) implies that income diversification per se cannot be used to associate the lower NPL ratio, because it is highly dependent on how banks diversify their income effectively. Thus, they suggest that income diversification and NPLs have no relationship. Table 1 shows the summary of literature review on non-performing loans determinants in the banking sector.

Table 1. Summary of literature on non-performing loans determinants in the banking sector

\begin{tabular}{|c|c|c|}
\hline $\begin{array}{c}\text { Bank-specific } \\
\text { Factor }\end{array}$ & Literature & $\begin{array}{c}\text { Relation } \\
\text { with NPLs }\end{array}$ \\
\hline Credit Growth & $\begin{array}{c}\text { Keeton (1999) } \\
\text { Ahmad \& Bashir (2013) } \\
\text { Boudriga et al. (2010) }\end{array}$ & $\begin{array}{c}\text { Positive } \\
\text { Positive } \\
\text { Negative }\end{array}$ \\
\hline Profitability & Rajan (1994) & Positive \\
& Berger \& De Young (1997) & Negative \\
\hline Operating & Berger \& De Young (1997) & $\begin{array}{c}\text { Positive } \\
\text { Efficiency }\end{array}$ \\
\hline Berger \& De Young (1997) & Negative \\
\hline Capital & Rajan (1994) & $\begin{array}{c}\text { Positive } \\
\text { Keeton \& Morris (1995) }\end{array}$ \\
\hline Income & Ghosh (2015) & Negative \\
Diversification & Hu et al. (2004) & None \\
\hline
\end{tabular}

\subsection{Regulation on Non-performing Loans (NPLs) in Indonesia}

In Indonesia, the asset of the banking sector continues to dominate its financial system; however, the ratio of bank assets to GDP is relatively low (50.8 per cent in 2016). Consequently, bank intermediation activity is also relatively low. In 2016, there were 115 commercial banks in Indonesia with different subjects of ownership, including state-owned banks, regional development banks, national private banks, joint ventures, and foreign banks. The Indonesian banking sector has successfully maintained its capital adequacy ratio (CAR) of 23 per cent well above the OJK's benchmark of 8 per cent.
After the Asian Crisis in 1997-1998, the Indonesian banking sector underwent restructuring processes aiming to strengthen the supervision function and to adopt good governance. The reforms involve taking from the establishment of the deposit insurance corporation (the Lembaga Penjaminan Simpanan/LPS) to the split of banking supervision between the central bank (the Bank Indonesia/ $B I)$ for macro prudential and the OJK for micro prudential regulations. Therefore, the OJK supports the Bl's macro prudential regulations through its roles in monitoring and assessing individual bank soundness and health indicators not only in the capital adequacy ratio (CAR) but also liquidity, solvability, profitability e.g., NIM), asset quality (e.g., NPLs), efficiency (e.g., operating expenses to operating revenue), and intermediary function (loan to deposit ratio/LDR).

In terms of NPLs, the $\mathrm{BI}$ requires commercial banks in Indonesia to maintain their NPL ratio under 5 per cent of their gross loans. NPLs in Indonesia are defined as the bank loans in which the debtors have not made their scheduled installments or interest payments for 90 days or more. The NPLs are then classified as sub-standard (SS), doubtful (D), and loss (L), regarding the earning assets quality (Bank Indonesia, 2012): (1) sub-standard: the debtor has not made his scheduled installments or interest payments between 90 to 120 days, (2) doubtful: the debtor has not made his scheduled installments or interest payments between 120 to 180 days, and (3) loss: the debtor has not made his scheduled installments or interest payments in more than 180 days.

The classification of NPLs related to loan loss provisioning is set aside by banks to cover potential losses on loans. Therefore, a high NPL ratio indicates low health of banks, since it influences banks' liquidity and performance. The high NPL ratio of particular banks is also associated with the systemic risk and effect to the whole banking sector, which lead to a financial crisis. For instance, prior to the Asian Crisis of 1997-1998, the Indonesian banking sector had a high NPL ratio of 49 per cent. In the aftermath, 60 commercial banks in Indonesia had to be closed down, and this disturbed the flow of funds in the economic system and adversely affected national economic growth. Having experiences with the financial crisis, the Parliament of Indonesia passed the Bill of Financial System Safety Net (the UU Jaring Pengaman Sistem Keuangan/JPSK) which serves as the legal basis for the Government of Indonesia, involving the Ministry of Finance, the OJK, the LPS, and the $\mathrm{BI}$, to prevent systematic dangers from the financial crisis. 


\section{Methodology}

Banking-industry data are retrieved from the balance sheet and income statements of individual banks from the S\&P Capital IQ database, while the supporting secondary data are acquired from the $\mathrm{BI}$, the OJK, and the World Bank from 2008 to 2015. Within the sample period, 115 commercial banks are listed in the Indonesian Stock Exchange. However, only 36 banks are selected due to the availability and completeness of the individual data. The dataset includes a balanced panel of 36 banks spanning 2008-2015 that results in 288 observations. Panel data contain cross-section units over multiple years, which are advantageous to enlarge the number of observations and degrees of freedom as well as to decrease collinearity among explanatory variables, particularly if the number of years is limited (Boudriga et al., 2010). Panel data are also beneficial to capture the bank-specific effects and unobservable differences among individual banks (Ghosh, 2015).

In this study, 5 bank-specific factors are applied as independent variables to comprehend NPLs in Indonesian commercial banking sector, namely: (1) credit growth, (2) profitability, (3) operating efficiency, (4) capital, and (5) income diversification as independent variables. NPL as the dependent variable is measured by the NPL ratio. All variables are expressed in ratio level. Table 2 shows how dependent and independent variables are measured.

Various estimation models are available for analyzing panel data: common effects, fixed effects, and random effects. The common effects estimation model is the simplest model that ignores the effect of time and individual banks (time- and cross section identifiers-invariant) due to the assumption that individual banks are homogenous and their behaviors are the same over time (Gujarati \& Porter, 2015). Consequently, the common effects model will have the same constant and coefficients across individual banks and over time (equation 4.1). $\alpha$

$$
Y_{t}=\alpha+\beta X_{t}+\epsilon_{t}
$$

The fixed effects model is estimated by controlling for unobserved heterogeneity over time (time-invariant) while allowing the varied behaviors across individual banks (cross-section identifiers). Therefore, the model has a different constant across individual banks, but the coefficients are fixed over time (equation 4.2).

$$
Y_{i t}=\beta X_{i t}+\varepsilon_{i t}
$$

The random effects model is estimated by allowing timevarying individual banks (Gujarati \& Porter, 2015). Therefore the random effects model has fixed coefficients, but the constant also consists of a random component (equation 4.3).

$$
Y_{i t}=\alpha+\epsilon_{i}+\beta X_{i t}+\theta_{i t}
$$

Equation 4.3 can be rewritten as:

$$
Y_{i t}=\rho_{i}+\beta X_{i t}+\theta_{i t}
$$

In order to identify whether the individual commercial banks in Indonesia have different behaviors and vary over time or not, it requires a selection process to choose the right estimation model. Therefore, the study caries out three distinct tests: (1) the Chow test to find whether the constant of the common effects (i.e., $\alpha$ in the equality 4.1 ) and the fixed

Table 2. Measurement of the dependent and independent variables

\begin{tabular}{|c|c|c|c|c|}
\hline Name of Variable & $\begin{array}{c}\text { Code of } \\
\text { Variable }\end{array}$ & Measurement & Formula & $\begin{array}{c}\text { Unit of } \\
\text { Measurement }\end{array}$ \\
\hline Non-performing Loan & NPL & Non-performing Loan Ratio & $\frac{\text { Non - performing Loan ( } \mathrm{t})}{\text { Total Loan }(\mathrm{t})}$ & Percentage \\
\hline Credit Growth & CG & Credit Growth Rate & $\frac{\text { Gross Loans }(\mathrm{t})-\text { Gross Loans }(\mathrm{t}-1)}{\text { Gross Loans }(\mathrm{t}-1)}$ & Percentage \\
\hline Profitability & ROAA & Return on Average Asset & $\frac{\text { Return on Asset }(\mathrm{t})+\text { Return on Asset }(\mathrm{t}-1)}{2}$ & Percentage \\
\hline Operating Efficiency & EF & Non-interest expense Ratio & $\frac{\text { Non interest expenses }(\mathrm{t})}{\text { Non interest income }(\mathrm{t})}$ & Percentage \\
\hline Capital & CAP & Equity-to-Asset Ratio & $\frac{\text { Total Equity }(\mathrm{t})}{\text { Total Asset }(\mathrm{t})}$ & Percentage \\
\hline $\begin{array}{c}\text { Income } \\
\text { Diversification }\end{array}$ & DIV & Non-interest Income Ratio & $\frac{\text { Non - interest Income }(\mathrm{t})}{\text { Total Income }(\mathrm{t})}$ & Percentage \\
\hline
\end{tabular}


effects (i.e., $\alpha_{i}$ in the equation 4.2) is significantly different, (2) the Hausman test to find consistency of the cross section-identifiers random effect (i.e., $\rho_{i}$ in the equation 4.4) over the fixed effects (i.e., $\alpha_{i}$ in the equation 4.2 ), and (3) the Lagrange Multiplier test to find the right model between the random effects and the common effects when the results of the Chow and the Hausman tests are still ambiguous.

The method used in this study for empirically investigating the relationship between NPLs and bank-specific variables is panel regression. Since the panel data set combines time series and cross sections, the residuals are likely to correlate across time and individual banks. Consequently, the ordinary least square (OLS) regression tends be biased. In order to solve the biasness of estimators, the residuals are clustered as suggested by Petersen (2009) before analyzing the estimation results.

The bank-specific variables model is given as:

$$
\begin{aligned}
N P L_{i t}= & \beta_{0}+\beta_{1} C G_{i t}+\beta_{2} R O A A_{i t}+\beta_{3} E F_{i t}+\beta_{4} C A P_{i t} \\
& +\beta_{5} D I V_{i t}+u_{i t}
\end{aligned}
$$

where $N P L_{i t}$ denotes the non-performing loan ratio for bank $i$ in period $t ; \beta_{0}$ denotes the intercept; $C G_{i t}$ denotes the credit growth for bank $i$ in period $t$; ROAA $A_{\text {it }}$ denotes the profitability for bank $i$ in period $t$; $E F_{i t}$ denotes operating efficiency for bank $i$ in period $t$; $C A P_{i t}$ denotes bank capital for bank $i$ in period $t$; $D I V_{\text {it }}$ denotes income diversification for bank $i$ in period $t ; i$ represents each state (36 banks); $t$ represents each year (2008-2015); and $\beta_{1}, \beta_{2}, \beta_{3}, \beta_{4}, \beta_{5}$ are the respective co-efficient terms.

\section{Results}

Table 3 shows the descriptive statistics of the dependent and independent variables: non-performing loan ratio, credit growth, profitability, operating efficiency, capital, and income diversification of 36 commercial banks listed at the Indonesian Stock Exchange over the period of 2008-2015.

Table 3. Descriptive statistics of the dependent and independent variables

\begin{tabular}{|c|c|c|c|c|c|}
\hline $\begin{array}{c}\text { Code of } \\
\text { variable }\end{array}$ & $\begin{array}{c}\text { No of } \\
\text { observation }\end{array}$ & Mean & $\begin{array}{c}\text { Standard } \\
\text { deviation }\end{array}$ & Minimum & Maximum \\
\hline NPL & 288 & $3.2 \%$ & $4.8 \%$ & $0.1 \%$ & $51.0 \%$ \\
\hline CG & 288 & $24.6 \%$ & $39.2 \%$ & $-92.9 \%$ & $480.0 \%$ \\
\hline ROAA & 288 & $0.9 \%$ & $4.6 \%$ & $-72.5 \%$ & $11.0 \%$ \\
\hline EF & 288 & $84.3 \%$ & $16.8 \%$ & $9.0 \%$ & $173.8 \%$ \\
\hline CAP & 288 & $12.5 \%$ & $6.9 \%$ & $-27.5 \%$ & $50.8 \%$ \\
\hline DIV & 288 & $10.6 \%$ & $6.8 \%$ & $-1.0 \%$ & $41.9 \%$ \\
\hline
\end{tabular}

The descriptive statistics in Table 3 show that the average NPL, credit growth, profitability, efficiency, capital ratio, and diversification rates are 3.2 per cent, 24.6 per cent, 0.9 per cent, 84.3 per cent, 12.5 per cent, and 10.6 per cent, respectively. The sample also clearly demonstrates that the commercial banks in Indonesia greatly vary. For instance, despite the fact that the average NPL ratio of 3.2 per cent is lower than the OJK's requirement of 5 per cent, the lowest NPL ratio is 0.1 per cent and the highest reaches 51 per cent. Furthermore, the average credit growth of 24.6 per cent, implying that banks generally increase their loans by almost 25 per cent from last year's total credits. In addition, there is a bank issuing loans by 5 times higher compared to last year's book, but there is also a bank that even reduces its credits by 93 per cent. This huge variation also appears in the return on average asset (ROAA), operating efficiency $(E F)$, capital (CAP), and income diversification (DIV). The static model applied in this study uses a fixed-effects estimation model. The results of the model are given in Table 4.

Table 4. Results of the fixed-effects panel regression model

\begin{tabular}{|c|c|c|c|c|}
\hline NPL & Coefficient & $\begin{array}{c}\text { Standard } \\
\text { error }\end{array}$ & $\begin{array}{c}\text { t- } \\
\text { statistic }\end{array}$ & Probability \\
\hline CG & -0.020 & 0.007 & -2.64 & 0.012 \\
\hline ROAA & -0.300 & 0.060 & -5.02 & $0.000^{\text {*** }}$ \\
\hline INEF & 0.080 & 0.071 & 1.12 & 0.269 \\
\hline CAP & 0.033 & 0.093 & 0.35 & 0.731 \\
\hline DIV & 0.163 & 0.130 & 1.26 & 0.215 \\
\hline Constant & -0.049 & 0.070 & -0.69 & 0.494 \\
\hline \multicolumn{3}{|c|}{ R $^{2}$} & \multicolumn{2}{|c|}{0.5879} \\
\hline Adj R & \multicolumn{2}{c|}{0.5211} \\
\hline \multicolumn{3}{|c|}{ F(5, 35) } & \multicolumn{2}{c|}{0.000} \\
\hline \multicolumn{3}{|c|}{ Prob>F } & \\
\hline
\end{tabular}

* Significance at the $10 \%$ level

** Significance at the $5 \%$ level

*** Significance at the $1 \%$ level

The results in Table 3 confirm that the five bank-specific factors are joint determinants of the NPL ratio indicated by a significant F-test (0.00) and a highly adjusted $R^{2}$ (52.11 per cent). Nevertheless, only profitability (ROAA) and credit growth (CG) are found to be significant. Both profitability and credit growth have negative relationships with the NPL. The results suggest that, at the 1 per cent significance level, a 1 per cent increase in profitability lowers the NPL by 5 per cent. Similarly, at the 5 per cent significance level, a 1 per cent increase in credit growth decreases NPL by 2.64 per cent. 


\section{Discussion}

Comparing our results with those of earlier studies, the negative relationship between profitability and the NPLs of Indonesian commercial banks diverges from what is proven by Rajan (1994) but is similar to the work of Berger and De Young (1997). In addition, the negative influence of credit growth on NPL contrasts the positive relationship found by Keeton (1999) and Ahmad and Bashir (2013); however, it supports the finding of Boudriga et al. (2010). In terms of operating efficiency, bank capital, and income diversification, our findings show that these factors do not influence NPLs, which conflicts with most of the previous research in various countries. However, an insignificant relationship between income diversification and NPL is persistent with what is found by Hu et al. (2004).

The negative relationship between profitability and NPL suggests that the more profit a bank gets, the less likely the bank is to have NPLs in the respective year. This is sensible because, when banks are highly profitable, they can perform proper management practices, including undertaking day-today operations as well as managing loan portfolios. More specifically, because they can afford a sufficient operating budget, they can perform adequate loan management such as underwriting, monitoring, and controlling. This is a preventive action to mitigate potential default risk to finally lower the possibility of having loan defaults in the banks' asset.

The negative impact of credit growth on NPL implies that banks issuing more credit tend to be more concentrated on credit activities so that they are more skillful in working with credit scoring, evaluation, and monitoring systems. By being specialized in lending activities, these banks can eventually reduce the number of NPLs in the current year. Another possibility to explain the negative relationship between credit growth and NPLs is that banks apply a liberal credit policy to reach a particular NPL ratio, especially to meet the OJK's requirement of 5 per cent. This liberal policy is carried out by restructuring the former credit terms of the insolvent loans, such as extending the terms of loans or softening the covenants, so that the debtors can remain current. In this case, the restructured loans might be recognized as the new loans, which are solvent. Alternatively, the banks can simply lend new money in order to increase total loans to get a lower NPL ratio. This makes sense because the NPL ratio is calculated by dividing the amount of non-performing loans by the total loans. Accordingly, an increase in credit supply is followed by the lower NPL ratio.

\section{Conclusions}

This study aims at understanding bank-level factors that determine non-performing loans (NPLs) in the Indonesian banking industry. By using a fixed-effects panel regression model, it is evident that NPLs in Indonesian commercial banks can be attributed to bank-specific factors, namely profitability and credit growth. In particular, banks with higher profits and credit growth are likely to have a lower amount of NPLs in their portfolio. These results shed light on the importance of micro-prudential surveillance on banks' lending behavior to restrain the level of NPLs.

With regards to the empirical finding on profitability, policy makers should require banks to be financially healthy by having adequate profits. By doing so, banks are capable of performing proper credit management processes, such as underwriting, monitoring, and controlling, that finally reduce the number of loan defaults in the banks' portfolio. Since banks' earnings predominantly come from interest income, it can be implemented by tightening supervision on credit management practices in the banking sector. Moreover, the government can formulate a particular minimum standard requirement on banks' profitability to make sure that banks can settle up on their operating expenses.

In addition, since credit growth evidently reduces the number of NPLs, banks should be encouraged to increase their credit supply and focus on lending activities. By being specialized, banks are expected to enhance their aptitude and ultimately lower the number of NPLs. However, an increase in credit supply will be exhilarating only if it is supported by the proper credit risk scoring (e.g. applying the $5 \mathrm{C}$ effectively) and management. Moreover, since there is a possibility that banks manufacture their NPL ratio calculation, the government should undertake additional analysis on banks' NPL calculation and formulation to avoid the delivery of misleading information.

Further investigations are needed to better identify the effect of bank-specific factors determining NPLs in different years by using a dynamic model. It is possible that banklevel determinants in the current year do not necessarily affect NPLs in the respective year but in other years.

\section{References}

Ahmad, F., \& Bashir, T. (2013). Explanatory Power of Bank Specific Variables as Determinants of NonPerforming Loans: Evidence from Pakistan Banking. World Applied Science Journal, 22, 1220-1231.

Alexandri, M. B., \& Santoso, T. I. (2015). Non-Performing Loan: Impact of Internal and External Factor (Evidence in Indonesia). International Journal of Humanities and Social Science Invention, 4(1), 8791.

Bank Indonesia. (2012). Bank Indonesia Regulation No. 14/ 15/PBI/2012 concerning Assessment of Commercial 
Bank Asset Quality. Retrieved April 10, 2018, from http://www.bi.go.id/en/peraturan/perbankan/Docume nts/b27692ce75294a62831cb7e39c423689PBI1415 2012ENG.pdf

Barseghyan, L. (2010). Non-performing Loans, Prospective Bailouts and Japan's Slowdown. Journal of Monetary Economics, 57(7), 873-890.

Beaton, K., Myrvoda, A., \& Thompson, S. (2016). NonPerforming Loans in the ECCU: Determinants and Macroeconomic Impact. IMF Working Paper WP 16/16/229.

Beck, R., Jakubik, P., \& Piloiu, A. (2015). Key Determinants of Non-Performing Loans: New Evidence from a Global Sample. Open Economies Review, 26(3), 525-550.

Berger, A., \& DeYoung, R. (1997). Problem Loans and Cost Efficiency in Commercial Banks. Journal of Banking and Finance, 21, 849-870.

Boudriga, A., Taktak, N. B., \& Jelloli, S. (2010). Bank Specific, Business and Institutional Environment Determinants of Banks Nonperforming Loans: Evidence from MENA Countries. Paper presented at the Economic Research Forum, Working Paper, 547, 1-28. Cairo, Egypt: The Economic Research Forum.

Deesomsak, R., Paudyal, K., \& Pescetto, G. (2004). The Determinants of Capital Structure: Evidence from the Asia Pacific Region. Journal of Multinational Financial Management, 14(4-5), 387-405.

Dimistrios, A., Helen, L., \& Mike, T. (2016). Determinants of Non-Performing Loans: Evidence from Euro-area Countries. Finance Research Letters, 18, 116-119.

Diyanti, A., \& Widyarti, E. (2012). Analysis of the Influence of Internal and External Factors on the Occurrence of Non-performing Loan (Case Study on Conventional Commercial Bank Providing Home Ownership Credit Service in 2008-2011). Journal of Management, 1(2). 290-299.

Ekanayake, E. M. N. N., \& Azeez, A. A. (2015). Determinants of Non-Performing Loans in Licensed Commercial Banks: Evidence from Sri Lanka. Asian Economic and Financial Review, 5(6), 868-882.

Ghosh, A. (2015). Banking-industry Specific and Regional Economic Determinants of Non-Performing Loans: Evidence from US States. Journal of Financial Stability, 20, 93-104.

Gujarati, D. N., \& Porter, D. C. (2015). Basic Econometrics (5th ed.). Boston: McGraw-Hill.

Hu, J. L., Li, Y., \& Chiu, Y. H. (2004). Ownership and Nonperforming Loans: Evidence from Taiwan's Banks. The Developing Economies, 42(3), 405-420.
Keeton, W. R. (1999). Does Faster Loan Growth Lead to Higher Loan Losses?. Federal Reserve Bank of Kansas City Economic Review, 2nd Quarter, 57-75.

Keeton, W., \& Morris, C. (1987). Why Do Banks' Loan Losses Differ Federal Reserve Bank of Kansas City, Economic Review, 72(5), 3-21.

Klein, N. (2013). Non-performing Loans in CESEE: Determinants and Impact on Macroeconomic Performance. IMF Working Paper WP/13/72.

Love, I., \& Ariss, R. T. (2013). Macro-Financial Linkages in Egypt: A Panel Analysis of Economic Shocks and Loan Portfolio Quality. IMF Working Paper WP/13/ 271.

Machrouch, F., Soedarmono, W., \& Tarazi, A. (2011). Bank Market Power, Economic Growth and Financial Stability: Evidence from Asian Banks. Journal of Asian Economics, 22(6), 460-470.

Moradi, Z. S., Mirzaeenejad, M., \& Geraeenejad, G. (2016). Effect of Bank-Based or Market-Based Financial Systems on Income Distribution in Selected Countries. Procedia Economics and Finance, 36, 510-521.

Otoritas Jasa Keuangan (OJK). (2017). Indonesian Banking Statistic 2017. Retrieved from http://www.ojk.go.id/ id/kanal/perbankan/data-dan-statistik/statistik-perban kan-indonesia/Pages/Statistik-Perbankan-Indonesia--Maret-2017.aspx

Petersen, M. A. (2009). Estimating Standard Errors in Finance Panel Data Sets: Comparing Approaches. Review of Financial Studies, 22(1), 435-480.

Poetry, Z. D., \& Sanrego, Y. D. (2011). The Effect of Macro and Micro Variables on NPLs of Conventional Banking and NPFs of Sharia Banking. Tazkia Islamic Finance and Business Review, 6(2), 79-104.

Rajan, R. (1994). Why Bank Policies Fluctuate: A Theory and Some Evidence. Journal Economics, 109, 399441.

Skarica, B. (2013). Determinants of Non-Performing Loans in Central and Eastern European Countries. Financial Theory and Practice, 38, 37-59.

Vatansever, M., \& Hepsen, A. (2013). Determining Impacts on Non-Performing Loan Ratio in Turkey. Journal of Finance and Investment Analysis, 2(4), 119-129.

Zeng, S. (2012). Bank Non-Performing Loans (NPLs): A Dynamic Model and Analysis in China. Modern Economy, 3, 100-110.

Zhu, N., Wang, B., \& Wu, Y. (2014). Productivity, Efficiency and Non-Performing Loans in the Chinese Banking Industry. The Social Science Journal, 52, 468-480. 